\title{
Maxilla Pseudoarthrosis Ten Years After Orthognathic Surgery: Case Report
}

\author{
Pseudoartrosis Maxilar Diez Años Después de \\ la Cirugía Ortognática: Relato de un Caso
}

Pedroso-Oliveira, G.1; Cavalieri-Pereira, L.2; Brancher, G. Q. B.1; Macedo, C. J. O. ${ }^{3}$; Cerezetti, L. ${ }^{4} \&$ Cavalieri-Pereira, S. ${ }^{5}$

\begin{abstract}
PEDROSO-OLIVEIRA, G.; CAVALIERI-PEREIRA, L.; BRANCHER, G. Q. B.; MACEDO, C. J. O.; CEREZETTI, L. \& CAVALIERI-PEREIRA, S. Maxilla pseudoarthrosis ten years after orthognathic surgery: Case report. Int. J. Odontostomat., 13(4):504-510, 2019.
\end{abstract}

ABSTRACT: Many orthodontic treatments alone cannot reestablish an ideal occlusion, requiring correction through orthognathic surgery. An adequate surgical planning, execution and case follow-up can provide surgical stability between the maxilla and the mandible. Soft tissue conservation and proper correction during a healing phase are important to achieving this goal. Patient C.L.B.S, 38 years old, female, presented with Angle Class I occlusion, facial profile class II, maxilla with mobility, chin surgically advanced and anterior open bite. She was submitted to orthognathic surgery 10 years ago. In the panoramic radiography the absence of bone formation in the maxilla was observed, causing an open bite. For the surgery conventional radiographs were used, as well as the dental cast in articulator for model surgery and preparation of surgical guide. With the surgery an improvement in the patient's aesthetics profile and an ideal occlusion, static and functional were expected. The treatment was orthodontic-surgical, with correction of the dento-facial deformity with counter-clockwise rotation of the maxilla, lowering repositioning in $3 \mathrm{~mm}$ of its posterior portion through Le Fort I osteotomy, advancement of the $4 \mathrm{~mm}$ mandible with bilateral sagittal osteotomy, and genioplasty for posterior repositioning with a Z-osteotomy, to improve mentual harmony. There was an improvement in the profile and aesthetics of the patient, which developed an Angle Class I profile, a decrease in the mentual projection, and an aesthetic and functional improvement. The orthognathic surgery allowed the advancement of the mandible, the repositioning of the maxilla and the mentual posterior repositioning, obtaining the correction of the Angle class II profile and the anterior open bite, resulting in an important improvement of facial profile and esthetics, presence of skeletal stability, restoration of function, self-esteem and quality of life.

KEY WORDS: orthognathic surgery, pseudoarthrosis, malocclusion, open bite.

\section{INTRODUCTION}

Ow \& Cheung (2009) and Chrcanovic \& Custódio (2011) proposed that the orthognathic surgery is frequently used to correct Class II and III deformities of the facial skeleton and maxillofacial asymmetries.

The osteotomies of the midface were used to correct zygomatic-maxillary deformities and, historically, were classified anatomically based on Guerin-LeFort fracture classification (Kim \& Park, 2007). The first LeFort I total osteotomy was performed by Wassmund in 1927 for correction of the skeletal open bite (Tabrizi et al., 2016). Despite all the advances in the field of orthognathic surgery, a variety of complications are documented.

\footnotetext{
${ }^{1}$ Resident of the residency training programn at the Departament of Oral and Maxillofacial Surgery of Hospital dos Fornecedores de Cana de Piracicaba, Brasil.

${ }^{2}$ Coordinator of the residency training programn at the Departament of Oral and Maxillofacial Surgery of Hospital dos Fornecedores de Cana de Piracicaba, Brasil.

${ }^{3}$ Intern of the residency training programn at the Departament of Oral and Maxillofacial Surgery of Hospital dos Fornecedores de Cana de Piracicaba, Brasil.

${ }^{4}$ Preceptor of the residency training programn at the Departament of Oral and Maxillofacial Surgery of Hospital dos Fornecedores de Cana de Piracicaba, Brasil.

${ }^{5}$ Plastic surgeon, member of the Brazilian Society of Plastic Surgery, Brasil.
} 
The "pseudoarthrosis" term, introduced by Weber \& Coch (1976), was used to denote the absence of consolidation of a long bone fracture by interposition of cartilaginous tissue and synovial epithelium between bone fragments. Spiessl (1988) used the term "nonunion" to describe the lack of mandibular fracture consolidation after six months of the surgery.

Kim et al. (2017) investigated the complication rate among 418 patients submitted to orthognathic surgery. They observed intraoperative complications, including inadequate osteotomy, vascular lesions with extensive bleeding, exposure and nerve damage, dental and soft tissue lesions, and postoperative complications, such as paresthesia due to nerve damage, dyspnea, cervical pain, gastrointestinal diseases, infections, open bite, relapse, temporomandibular disorders (TMD) and pseudoarthrosis or non-union of bone fractures.

\section{CLINICAL CASE REPORT}

Patient C.L.B.S, 38 years old, female, leucoderma, came to the Oral and Maxillofacial Surgery Service of Hospital dos Fornecedores de Cana de Piracicaba having as complaint her maxilla that was mobile and her chin that had a pointed and circular appearance. The patient had been submitted to orthognathic surgery 10 years ago, with the superior repositioning of the maxila and mentoplasty, according to her report.

On clinical examination, the movement of the maxilla to the manipulation was noted, concluding the diagnosis of maxilla pseudoarthrosis. Besides that, the Angle Class II profile, and the anterior projection of the chin was evidenced.

In frontal view of the patient (Fig. 1A), was noted abscence of facial harmony, a disproportionate face, due to the increase of the lower face in relation to the other facial thirds - midface $-61 \mathrm{~mm}$; lower face -75 $\mathrm{mm}$ - the absence of a nasolabial fold a slightly pronounced mandibular contour, and a pronunced and pointed chin in a circular shape. Also, noted was the muscular force made by the pacient for lip sealing.

In a lateral (Fig. 1B) view, there was a normal nasolabial angle, the chin salient projection, a convex profile, a pronounced mentolabial fold, causing facial disharmony, a lower lip protruding in relation to the true vertical line (TVL) and everted due to premature touch in the upper incisors.

In intraoral view (Fig. 1C), there is an orthodontic relapse of the patient's occlusion. There is an anterior open bite with premature contacts in the posterior teeth, which probably caused the pseudoarthrosis. Besides that, the relation of canines in Angle Class II was noticed. The patient had some gyroscopic and inclined teeth, which was not corrected pre-surgically, because the orthodontic appliance was installed a few weeks before the surgery, and there was no orthodontic correction due to the clinical situation.
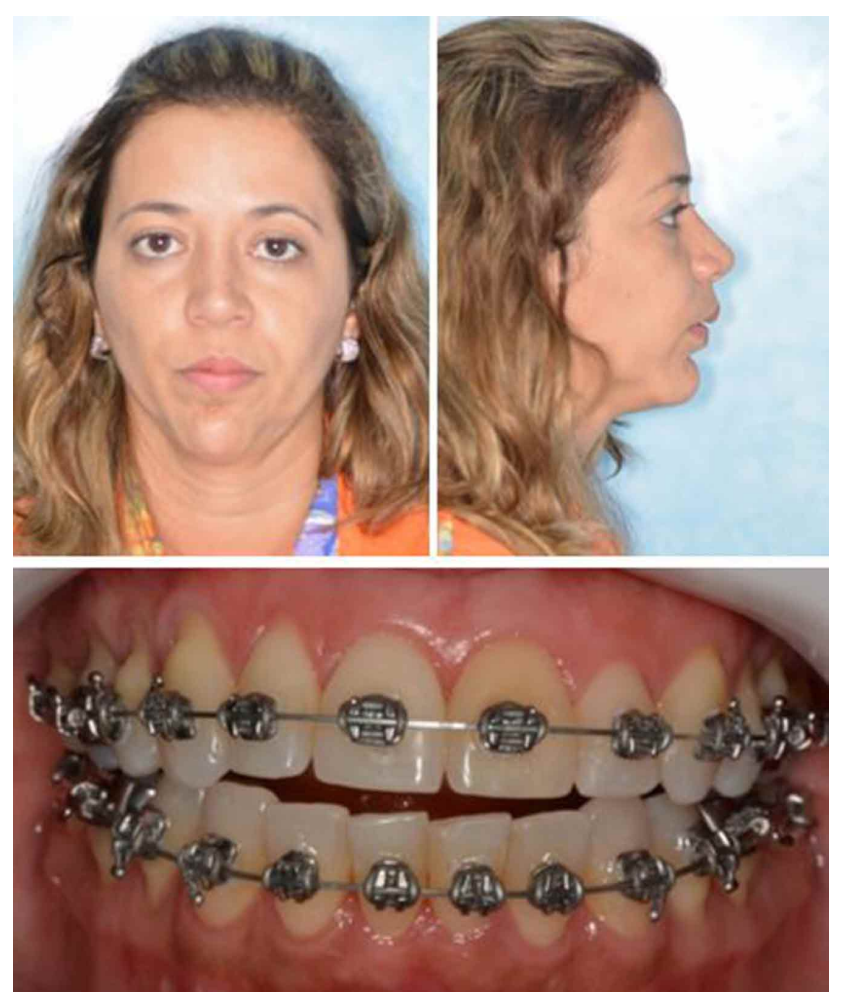

Fig. 1. Photos taken preoperatively. A. With lips at rest. B. Profile photo. C. Intraoral view showing the anterior open bite, and a premature posterior occlusal contacts.

After facial analysis, the panoramic radiograph (Fig. 2) and lateral cephalogram (Fig. 3A) and dental cast were analyzed, concluding that diagnosis was of dentofacial Class II deformity with vertical maxillary excess and anteroposterior mandible deficiency.

In cephalometric analysis (Fig. 3B) made from the lateral cephalogram (Fig. $3 \mathrm{~A}$ ), was observed an open and increased mandibular plane in relation to the Frankfurt Horizontal plane (FHP); a relationship between the long axis of lower central incisor and the 


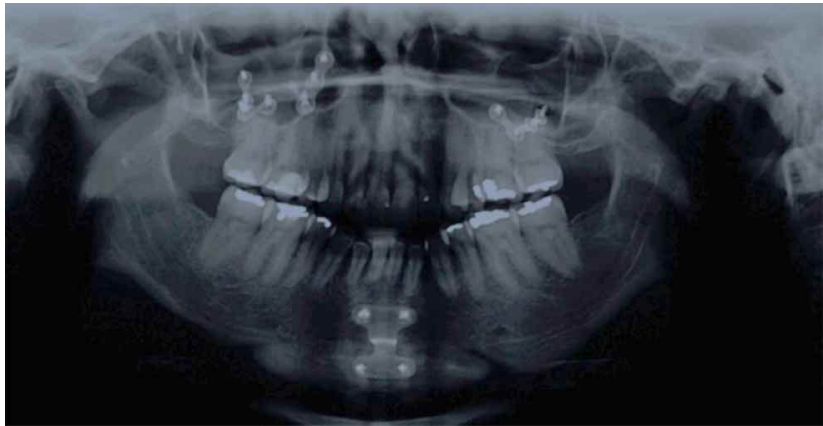

Fig. 2. Panoramic radiograpy preoperative showing the incorect maxilla fixation.

mandibular plane (IMPA) increased that could not be decompensated orthodontically, due to the severity of the clinical case.

The prediction tracing was performed (Fig. 3C), where the conter-clockwise rotation of the occlusal plane was established, with rotation axis at the point between the incisors. The posterior part of the maxilla was repositioned inferiorly in $3 \mathrm{~mm}$, the mandible was advanced in $4 \mathrm{~mm}$, and the chin was repositined posteriorly in $10 \mathrm{~mm}$, returning to its natural position, giving more harmony to the face.

The surgery was performed at the hospital, under general anesthesia with nasotracheal intubation. A mucoperiosteal flap was performed by a rectilinear horizontal incision, extending from buccal vestibular space of the upper first molar to the contralateral first molar. When the flap was detached, the region of the anterior wall of the maxillary sinus, nasal pyriform aperture, nasal septum and nasal fossa floor were exposed (Fig. 4A). The three plates found in the maxilla were removed. The Le Fort I osteotomy line is located at least $5 \mathrm{~mm}$ above the dental apices and extends from the zygomaticomaxillary crest, posteriorly to the nasal pyriform aperture, anteriorly. The Le Fort I osteotomy was performed with counter-clockwise rotation of the maxilla and repositioning of its posterior part in $3 \mathrm{~mm}$. After the downfracture, the pseudoarthrosis was removed with surgical drill wear. With the installation of the intermediate occlusal wafer, four L-plates of the system 2.0 at the nasomaxillary and zygomaticomaxillary buttresses were fixed. The 2.0 system was used for better stability (Figs. 4B-C). Due to extensive GAP found after the pseudoarthrosis removal was interposed lyophilized bone graft therein.

In the mandible, local anesthetic with vasoconstrictor was carried out in mandibular vestibular space of a mucoperiosteal flap. A bilateral sagittal osteotomy was performed on mandibular ramus (SRRO) with reciprocating saw and chisels. The osteotomy should be made as rectilinear as possible, to avoid unwanted fractures. The mandible was advanced in $4 \mathrm{~mm}$ with the installation final occlusal wafer. A hybrid technique was applied with two positional bicortical screws and one straight plate of the system 2.0 on each sagital osteotomy
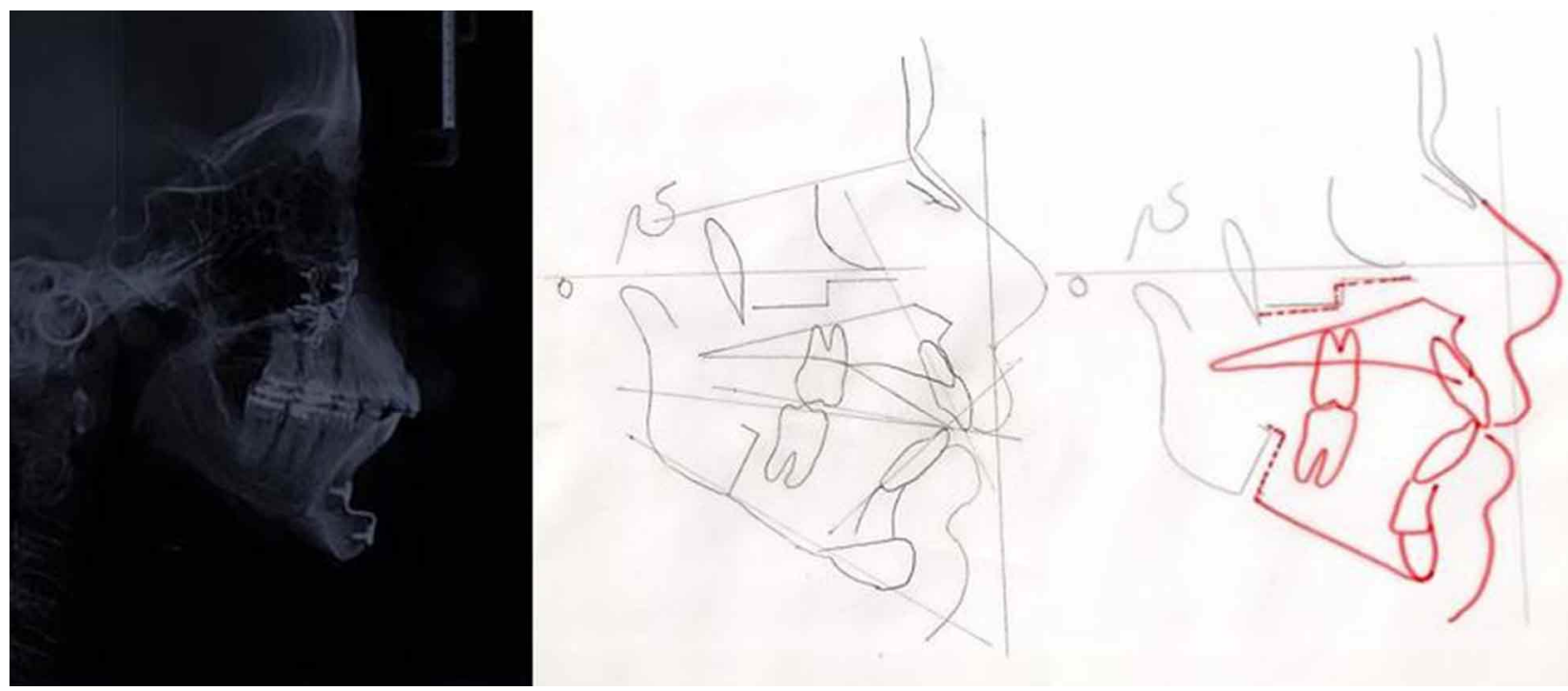

Fig. 3A. Preoperative lateral cephalogram confirming the retrognathic mandible with a anterior mentual projection. B. Cefalometric analysis. C. Superpositioning of the pre-and postoperative tracing of the lateral cephalogram. Red line: postoperative. The class I occlusion was obtained with the advancement of the mandible, the lower face is diminished by the rotation counter-clockwise of the occlusal plane and posterior repositioning of the chin. The increase of the incisor inclination due to the lack of orthodontic treatment is noted prior to surgery. 

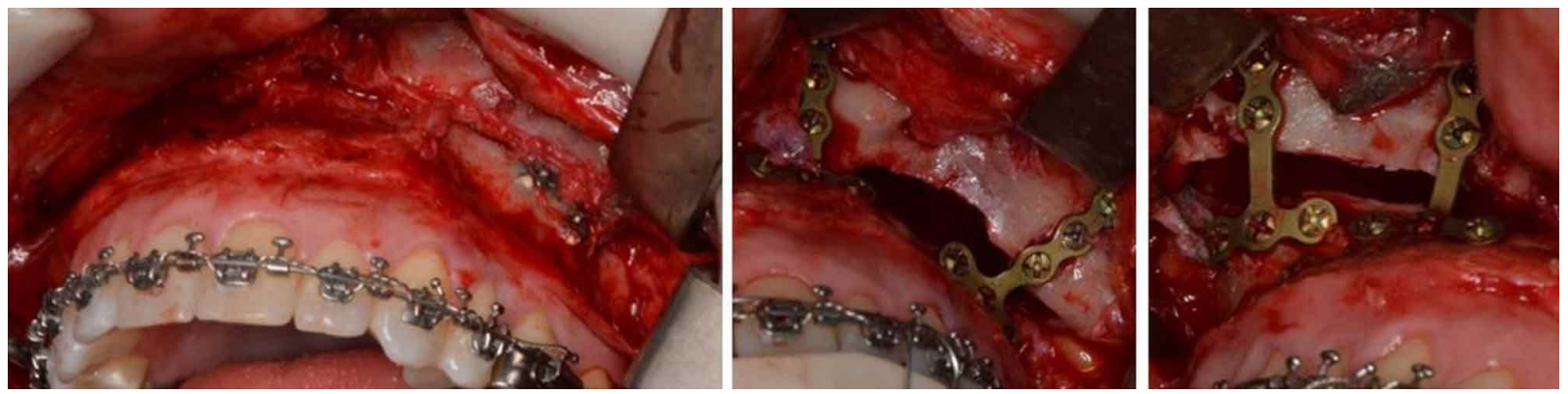

Fig. 4A. Intraoperative maxilla, showing the pseudoarthrosis. B-C. Internal fixation of the maxilla, in the nasomaxillar and zygomaticomaxillar buttress.
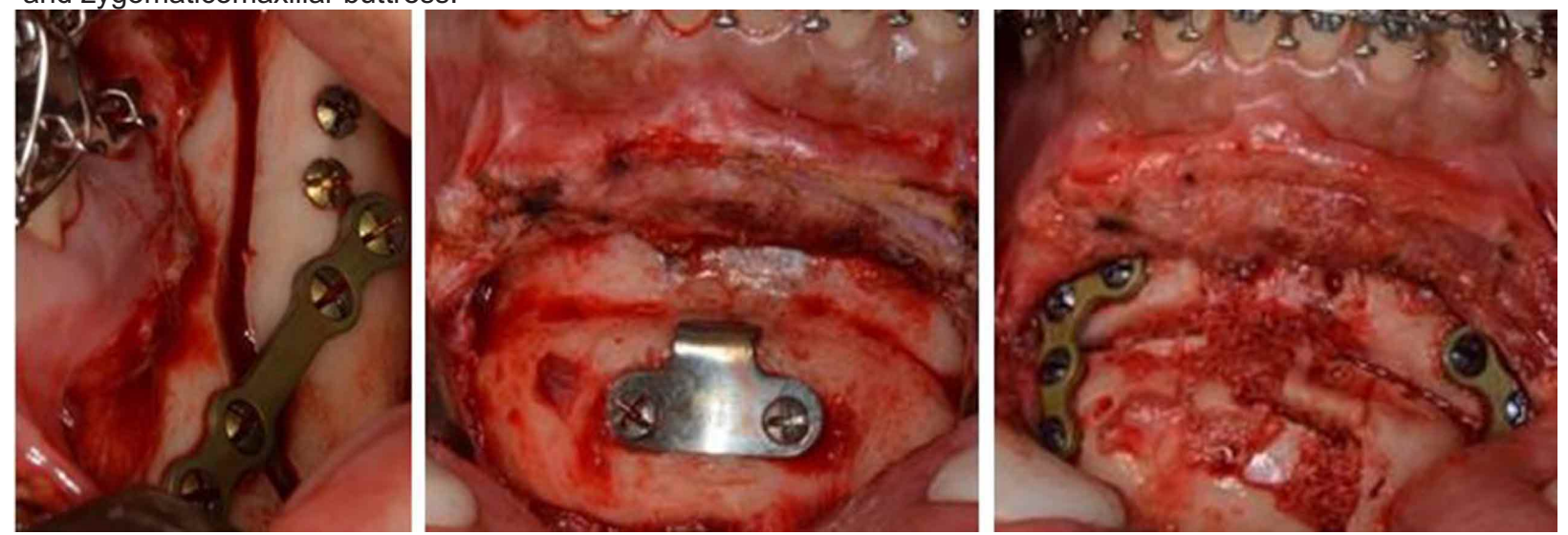

Fig. 5A. Internal fixation of the mandibular ramus with the hybrid techinique. B. Intraoperative inicial chin aspect. C. Internal fixation of the chin and the interposition of lyophilized bone graft.
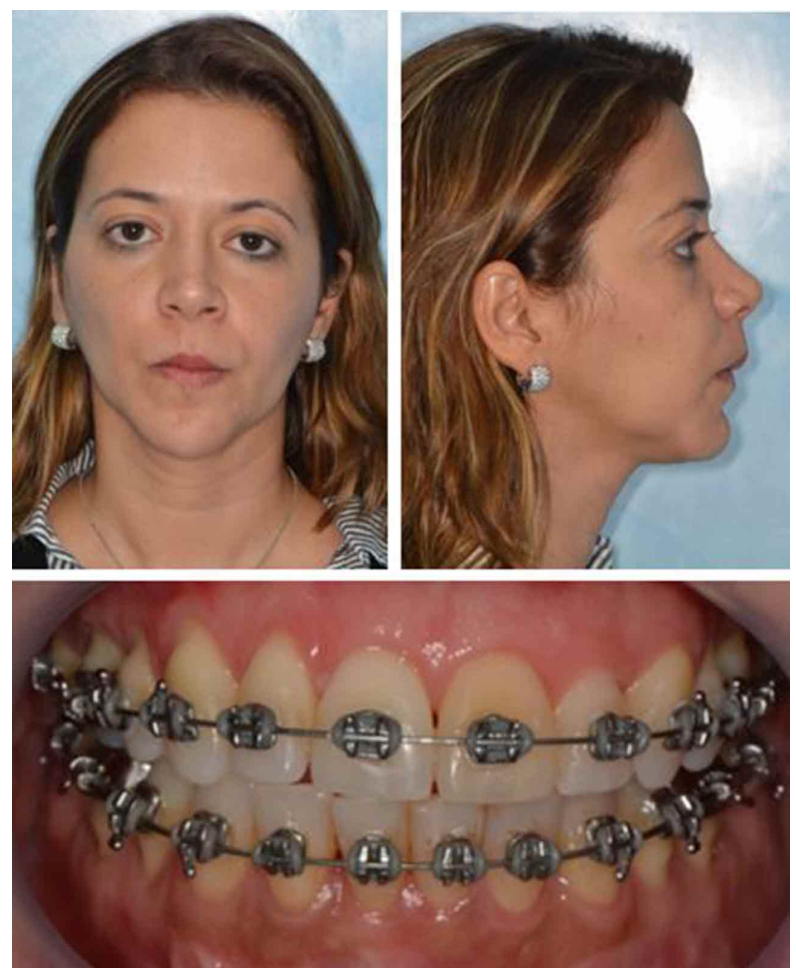

Fig. 6. Photos taken 4 months postoperatively A. with lips at rest. B. Profile photo C. Intraoral postoperative view showing the occlusal correction.
(Fig. 5A). The next step was the mentolasty. A mucoperiosteal incision was performed in the anterior region, with detachment of the mentual muscle, to remove the Paulus plate (Fig. 5B), and to perform the osteotomy for mentoplasty. The mentoplasty had a posterior repositioning of the chin in $10 \mathrm{~mm}$ and a step osteotomy $(Z)$ - which had the interposition of the lyophilized bone graft (Fig. 5C) - for a better mentual harmony - one of the patient's main complaints. The fixation was done with $2.0 \mathrm{~mm}$ plates and screws.

In the postoperative period of 10 months, the top bite and a canines Class I occlusion were verified (Fig. 6C). The patient is in orthodontic treatment to the case finalization. In the frontal view (Fig. 6 A) can be noticed the correction of lower face height, the presence of a nasolabial fold, a more pronounced mandibular angle, and a greater chin harmony. The patient has labial ptosis because of the two surgeries performed that caused fibrosis to the mentual muscle, the reason the patient forces the orbicularis muscle of the lip for lip sealing. She has already been sent to speech therapist for improvement and resolution of the clinical case. In the lateral (Fig. 6B) view, the patient has a more harmonious profile and mentual projection, a normal lower lip, and a shallower mentolabial fold. 
Panoramic radiography is shown in Figure 7, showing the plates correctly positioned and fixed.

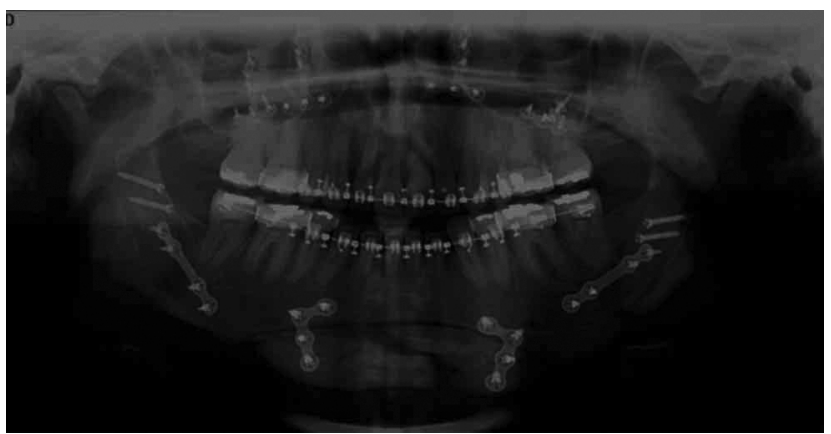

Fig. 7. Panoramic radiograpy postoperative showing the correct internal fixation of the maxilla.

\section{DISCUSSION}

The occurrences of complications in orthognathic surgery are challenging to the surgeon, who must be prepared to solve the problem and finalize the surgical procedure as planned, or even plan a reintervention surgery. According to Van Sickels \& Tucker (1990), the risk of non-union of the jaws is high when the internal fixation is performed inadequately; when the anterior displacement of a bone segment is large or when the maxillary advancement is bigger than $6 \mathrm{~mm}$; when preoperative occlusal contacts interfere with the stabilization and healing of bone segments and in patients with systemic diseases that have impairment in healing process. Items 1 and 3 of the published work can explain the clinical case of the paciente presented.

Bays (1997) reported that pseudoarthrosis is a relatively common complication in maxillary surgeries. Extensive periods of postoperative maxilla mobility are rare, but it may occur in the presence of a traumatic occlusion - as in the introduced case. When atooth is in premature contact during the occlusion, there is an imbalance of the maxilla forces, causing the mobility of the maxillary bone. If this movement is routine, a fibrosis union develops, delaying healing results. If maxillary movement persists for many weeks, vertical bone resorption may occur, causing the vertical bone resorption. The occlusion should be carefully monitored to ensure that the maxilla is not being mobilized. If the mobilization of the maxilla is observed, measures should be taken to allow the bone healing.

Several studies cite the postoperative surgical complications that may occur in orthognathic surgeries.
The following works, by Haas Junior et al. $(2016,2017)$, lannetti et al. (2013), Je drzejewski et al. (2015) and Panula et al. (2001), cite as most common TMD and damage to the mandibular nerve. Pseudoarthrosis, however, rarely happens in all of them.

Haas Junior et al. (2017) published a systematic review where 2078 patients underwent orthognathic surgery in nine different studies. Among them, only 187 patients evaluated had surgical complications, of which only $1.6 \%$ were pseudoarthrosis.

In the study of lannetti et al., according to the data collected, 2407 of $3236(74.4 \%)$ of the patients who underwent surgery had a normal postoperative period without complications during the follow-up. However, in $829(25.6 \%)$ of the cases, one or more surgical complications occurred. The most frequent complication was a neurosensory deficit related to the mandibular nerve, in $19 \%$ of the cases. The postoperative TMD was found in $11.17 \%$. Pseudoarthrosis, occurred only in $0.09 \%$ of the cases presented by the authors.

In a systematic review made by Je,drzejewski et al., the authors framed 44 articles in his inclusion criterias. In these articles, the most frequent complication was nerve damage or altered sensitivity in $50 \%$ of the cases. Pseudoarthrosis occurred in 4.55 $\%$ of the cases.

In a review of cases conducted in Finland by Panula et al., between 1983 and 1996, with 655 patients, pseudoarthrosis was found only in 2 patients. The most frequent complications were loss of sensitivity in the inferior alveolar nerve (183 patients) and TMDin 167 patients.

Rohner et al. (2013) published a paper with the objective of evaluating if a bone substitute can be used to promote bone union in patients submitted to maxillary advancement after Le Fort I osteotomy. Nine patients were treated bilaterally with Le Fort I osteotomies and maxillary advancements of $5 \mathrm{~mm}$ or less. In each patient it was grafted a Bio-Oss $®$ Collagen bone substitute. The contralateral side was left with GAP and served as control group. After 6 months, there was still GAP in the sites of the control group in 3 patients, while in the grafted sites all GAPs were completely filled with bone. The histomorphometric analysis performed with the region biopsies showed a similar amount of bone formation in both groups, however, in the group with GAPs filled with Bio Oss $₫$ the average amount of the mineralized bone 
fraction was higher than the control group. Therefore, the authors concluded the bone substitute may be an appropriate material to promote bone union in the Le Fort I osteotomies in advancements of $5 \mathrm{~mm}$ or less.Further studies are needed to analyze whether this technique is efficient in preventing recurrence and promoting bone union in major advances.

Unlike Rhoner et al., Araujo et al. (1978) published a study where they said that the increase in relapse and non-union occurred only in major maxillary advances. Failure to form adequate bone bridges in the region where a large GAP existed could result in delayed union or non-union. It was then recommended that bone grafts be placed in the region of the pterygoid plaque when the maxilla was advanced more than $6 \mathrm{~mm}$. As the existing GAP between the Le Fort I osteotomy after removal of pseudoarthrosis was bigger than $6 \mathrm{~mm}$, corroborating with the study of Araujo et al., was opted for the interposition of the lyophilized bone.

Haas Junior et al. (2016), corroborating with Araujo et al., publisheda case report saying that to avoid the risk of maxillar pseudoarthrosis, the authors used bone graft: $2 \mathrm{~g}$ of small Bio-oss $®$ granules in surgical GAPs, since the maxillary repositioning would be $5 \mathrm{~mm}$ inferiorly, according to the virtual planning,. These areas were then covered with a Bio-Gide $\AA$ collagen membrane. After six months, a new CT scan was performed, which revealed bone formation with a density greater than the controled group, providing stability in occlusion.

\section{CONCLUSION}

Pseudoarthrosis is an uncommon complication, but likely to occur if the maxilla is not fixed correctly. The treatment involves a surgical reintervention. In the surgical reintervention, the patient obtained gains in facial esthetics. There were important advancesin the mandible that eliminated the antero-posterior soft tissue deficiency, and resulted in a better definition of the cervico-mandibular angle. The posterior repositioning of the chin deleted the mentual discrepancy. The repositioning of the maxilla resulted in a more aesthetic exposure of the upper incisors during the smile, besides a stable internal fixation adequate, without the movement of the maxilla. The results promoted the improvement of the function, facial aesthetic balance and skeletal and occlusal stability of the patient, bringing her satisfaction.
PEDROSO-OLIVEIRA, G.; CAVALIERI-PEREIRA, L.; BRANCHER, G. Q. B.; MACEDO, C. J. O.; CEREZETTI, L. \& CAVALIERI-PEREIRA, S. Pseudoartrosis maxilar diez años después de la cirugía ortognática: relato de un caso. Int. J. Odontostomat., 13(4):504-510, 2019.

RESUMEN: En muchos casos, el tratamiento ortodóntico por si solo no puede restablecer una oclusión ideal, siendo necesaria una cirúrgia ortognática. Una buena planificación quirúrgica, ejecución y seguimiento del caso, pueden proporcionar estabilidad entre los maxilares. La preservación de los tejidos blandos y una fijación adecuada son esenciales para ese objetivo. La paciente CLBS, 38 años, se presentó con oclusión Clase I de Angle, teniendo perfil clase II, maxilar con movilidad, mentón quirúrgicamente avanzado y mordida abierta anterior. La paciente fue sometida a cirugía ortognática 10 años antes. En radiografía panorámica, se nota la ausencia de formación ósea debido a una fijación maxilar realizada erróneamente, lo que causó la mordida abierta. Durante la planificación, fueron utilizadas radiografías convencionales, modelos de yeso en articulador para cirugía de modelo y confección de guía quirúrgica. Con el procedimento quirúrgico se esperaba obtener una mejora en el perfil de la paciente y una oclusión ideal, estática y funcional. El tratamiento fue ortodóntico-quirúrgico, con corrección de la deformidad dento-facial con giro antihorario de la mandíbula, con reposicionamiento inferior de $3 \mathrm{~mm}$ de su parte posterior, por medio de osteotomía Le Fort I, avance de la mandíbula de $4 \mathrm{~mm}$ con osteotomía sagital bilateral, y retroceso del mentón en su posición original con osteotomía en Z, mejorando la armonía del mentón. Hubo una mejora en perfil y en la estética de la paciente, como también una mejora en el perfil, estética y funcionalidade, con diminución del mentón. La cirúrgia ortognática permitió el movimiento de la mandíbula, reposicionamiento maxilar y además fue posible retroceder el mentón, obteniendo la corrección del perfil Clase II y de la mordida abierta anterior. El resultado representa una mejora del perfil y de la estética facial, además se nota una estabilidad esquelética, con restablecimiento de la función, autoestima y calidad de vida.

PALABRAS CLAVE: cirugía ortognática, pseudoartrosis, maloclusión, mordedura abierta.

\section{REFERENCIAS BIBLIOGRÁFICAS}

Araujo, A.; Schendel, S. A.; Wolford, L. M. \& Epker, B. N. Total maxillary advancement with and without bone grafting. J. Oral Surg., 36(11):849-58, 1978.

Bays, R. A. Complications Of Orthognathic Surgery. In: Kaban, L. B.; Pogrel, M. A. \& Perrot, D. H. Complications In Oral And Maxillofacial Surgery. Philadelphia, Saunders, 1997. pp.193222.

Chrcanovic, B. R. \& Custódio, A. L. Optic, oculomotor, abducens, and facial nerve palsies after combined maxillary and mandibular osteotomy: case report. J. Oral Maxillofac. Surg., 69(6):e234-41, 2011. 
Haas Junior, O. L.; da Silva Meirelles, L.; Scolari, N.; Emmel Becker, O.; Fernandes Santos Melo, M. Belle de Oliveira, R. Bone grafting with granular biomaterial in segmental maxillary osteotomy: A case report. Int. J. Surg. Case Rep., 25:238-42, 2016.

Haas Junior, O. L.; Guijarro-Martínez, R.; de Sousa Gil, A. P.; da Silva Meirelles, L.; de Oliveira, R. B. \& Hernández-Alfaro, F. Stability and surgical complications in segmental Le Fort I osteotomy: a systematic review. Int. J. Oral Maxillofac. Surg., 46(9):1071-87, 2017.

lannetti, G.; Fadda, T. M.; Riccardi, E.; Mitro. V. \& Filiaci, F. Our experience in complications of orthognathic surgery: a retrospective study on 3236 patients. Eur. Rev. Med. Pharmacol. Sci., 17(3):379-84, 2013.

Jedrzejewski, M.; Smekta?a, T.; Sporniak-Tutak, K. \& Olszewski, R. Preoperative, intraoperative, and postoperative complications in orthognathic surgery: a systematic review. Clin. Oral Investig., 19(5):969-77, 2015

Kim, S. G. \& Park, S. S. Incidence of complications and problems related to orthognathic surgery. J. Oral Maxillofac. Surg., 65(12):2438-44, 2007.

Kim, Y. K. Complications associated with orthognathic surgery. J. Korean Assoc. Oral Maxillofac. Surg., 43(1):3-15, 2017.

Ow, A. \& Cheung, L. K. Skeletal stability and complications of bilateral sagittal split osteotomies and mandibular distraction osteogenesis: an evidence-based review. J. Oral Maxillofac. Surg., 67(11):2344-53, 2009.

Panula, K.; Finne, K. \& Oikarinen, K. Incidence of complications and problems related to orthognathic surgery: a review of 655 patients. J. Oral Maxillofac. Surg., 59(10):1128-36, 2001.

Rohner, D.; Hailemariam, S. \& Hammer, B. Le Fort I osteotomies using Bio-Oss $₫$ collagen to promote bony union: a prospective clinical split-mouth study. Int. J. Oral Maxillofac. Surg., 42(5):58591, 2013.

Spiessl, B. Non-Union. In: Spiessl, B. (Ed.). Internal Fixation of the Mandible. A Manual of AO/ASIF Principles. Berlin, Springer Verlag, 1988. pp.272-9.

Tabrizi, R.; Pakshir, H. \& Nasehi, B. Does the Type of Maxillomandibular Deformity Influence Complication Rate in Orthognathic Surgery? J. Craniofac. Surg., 26(7):e643-7, 2016.

Van Sickels, J. E. \& Tucker, M. R.; Management of delayed union and nonunion of maxillary osteotomies. J. Oral Maxillofac. Surg., 48(10):1039-44, 1990.

Weber, B. G. \& Coch, O. Pseudarthrosis. New York, Stratton, 1976.
Corresponding author:

L. Cavalieri-Pereira

Coordinator of the residency training program at the Departament of Oral and Maxillofacial Surgery Hospital dos Fornecedores de Cana de Piracicaba BRAZIL

Email: dr.lucasmaxilofacial@hotmail.com

Received: 05-06-2019

Accepted: 25-07-2019 